\title{
屋敷構えから見た農村系長屋門の配置に関する研究 \\ 栃木県宇都宮市における事例的検討 \\ LAYOUT OF NAGAYA-MON GATE IN RURAL AREA FROM A VIEWPOINT OF SETTING UP PREMISES
}

A case study of Utsunomiya city in Tochigi prefecture

三橋伸夫*, 本庄宏行**

Nobuo MITSUHASHI and Hiroyuki HONJO

\begin{abstract}
The paper aims to clarify layout conditions of the Nagaya-mon gate focusing on setting up premises of farmhouse. Utsunomiya city in Tochigi prefecture were chosen for investigation of map surveys on web browser and field studies. All gates in the city were categorized into several types from view-points of gate's attributes, such as orientation, common axis with main house, and connection with public road adjacent to the site. Typical patterns of premises' layout are found as follows: 1) both main houses and Nagaya-mon gates mostly face the south; 2) layout of the premises shows that main house and Nagaya-mon gate have common axis along each approach with parallel position; 3) Nagaya-mon gate mainly faces minor public roads or private roads. Considering the transition of the surroundings, original Nagaya-mon gate is assumed to have a private road on its own site.
\end{abstract}

Keywords : Nagaya-mon Gate, Setting up premises, Utsunomiya city, Layout, Transition 長屋門，屋敷構え，宇都宮市，配置，変遷

\section{1.はじめに}

長屋門は建設時から時代の変化と共に様々な空間変化や用途変遷 を経て現在に至っている。それは歴史を体現するものとして、農村 風景に落ち着いたたたずまいを見せる。J. ラングは、古い建物はわ れわれに歷史の感覚、永続性の感覚を与えること、そして大きな社 会変動はしばしば古い建物を保存する動きを伴う、なぜならそれは 人生に安定を与えてくれるように感じるからである、と述べている 注 1)。こうした意味で長屋門は地域の歴史を伝える貴重な存在と言 える。とはいえ、長屋門は一般に母屋に対する付属舎と見なされ、 独立して文化財に指定、登録されることは稀である。修復など文化 財としての保存も母屋と一体でなされることが多い。

こうしたことは、言い換えるならば、長屋門は母屋を中心とした 家屋敷を構成する重要な要素として認識され、屋敷構えに欠かせな い存在であることを示している。長屋門は建物単独ではなく、母屋 との関係においてとらえるべきであるという研究の視角が導かれる。 そこで本研究では、栃木県宇都宮市の長屋門をもつ家屋敷を対象と して、屋敷構えから母屋と長屋門との関係を明らかにして、長屋門 が周辺環境に対してどのような関係を築いているのかを探ることを 目的とする。
一般的に言って、屋敷は住み手の内的要求と対社会的関係が投影 されて構え方の形式が整えられると考えられる注2)。長屋門は、まさ にこのような屋敷の構え方の結果として表現された一つの要素であ り形式であると言え、長屋門を単にひとつの建物として扱うだけで はその本質をとらえることはできない。本研究において屋敷構えに 着目する理由はそこにある。

本研究で用いる屋敷構えとは、屋敷を構成するさまざまな要素、 すなわち、住宅を含む建物、庭、屋敷境界、出入口等の組み合わさ れた全体的な様相を指す注 3)。月舘が指摘するように、屋敷構えを検 討する場合、特に道路に対する構え方が重要である。それは、道路 からの屋敷の見え方は対社会性を表出していると考えられるからで ある注 4)

屋敷構えとして見た場合、長屋門は屋敷を構成する要素の一つで ある。しかし、それは建物であると同時に、垣根などと同様に屋敷 の外との境界を区切るものでもあるという複合的な性格をもつ。こ のような意味で、屋敷構えの観点から長屋門を扱った研究は見当た らず、ここに本研究の独創性がある。

長屋門は、屋敷を構成する重要な要素である住宅（母屋）と対比 した場合には付属的な要素であることは異論がないであろう。こう
* 宇都宮大学 名誉教授 とちぎ協働デザインリーグ 理事長・工博

** 宇都宮大学地域デザイン科学部技術部 技術専門職員
Honorable Prof., Utsunomiya University /

President, Tochigi Partnership Design League, Dr. Eng.

Technical Staff, Faculty of Regional Design, Utsunomiya University 
した理由から、長屋門を扱った研究は少ないと言えるが、一方、屋 敷構えを扱った研究は数多い。その対象となるのは、既成市街地内 の伝統的な町屋から、地方都市の一般的な住宅、さらには農村、漁 村ときわめて幅広い。農村集落における農家（農村住宅）の屋敷構 えを扱った既往研究として、黒野らによる研究がある注5)注 6)。これ ら屋敷構えの研究からは、水路や街路の中心性、方向性に呼応した 街路村における屋敷構えの構成、雪処理を軸にした環境システムと しての屋敷構えの構成、などの知見が得られている。

\section{2. 研究方法と調查方法}

\section{2-1 母屋および道路との関係から見た長屋門の分類}

杤木県宇都宮市内の長屋門を対象としてインターネット上の地図 及び現地踏查により長屋門の立地を特定し、長屋門をもつ家の屋敷 構えから見た長屋門について、アプローチ、母屋との関係、長屋門 の方位、通行機能の 4 点に着目し、これらから分類を行う。対象は 市内 156 棟の長屋門である。

アプローチでは、長屋門が面する道路のヒエラルキーおよび有無 から I 〜 IV、母屋との関係では、母屋と長屋門が同一軸上にあるか

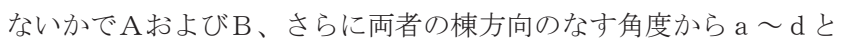
区分した（Fig.1）。長屋門の方位は主たる方角を判断して東西南北 の 4 通り、長屋門の通行機能は人、自動車に着目して 3 通りとした。

分類結果を Table1 に示す。

先に屋敷構えは道路との関係を重視すると述べたが、武家の長屋 門（市街地系長屋門）の場合は、一般に敷地の制約から、長屋門は 道路に接し棟方向を平行にして配置すると考えられるが、敷地の制 約が相対的に小さい農村系長屋門注7)では、道路と門との間に緩衝帯 をとる、すなわち道路（公道）から私道を延ばし、その延長上に門 を構える場合が多い。本研究ではこれを農村系長屋門の基本型とし て仮説的にとらえた（Photo1、Photo2）。

\section{2-2 典型事例への聞き取り調査と実測調査}

分類結果 (Table1) より、典型的な 5 つの類型（II/Aa、III/Aa、 II / Ab、III/Ab、II/Bc）から 1 棟ずつ選び、長屋門所有者への聞き 取り調查と長屋門と敷地内の実測調查を実施し、写真撮影と図面採 取を行い、得られた情報を整理する。選定に際しては、各類型に該 当する例数の多いものを典型と判断し、市街地縁辺部から農村平地 部、農村山間部まで地形や市街化程度などの立地条件にも配慮した。

\section{3. 調査結果と考察}

\section{3-1 屋敷構えから見た長屋門の分類結果}

\section{(1) アプローチ・母屋との関係について}

母屋と長屋門の中心が一直線上にある（軸上）場合、母屋と長屋 門の棟がな寸角度（傾き）は $5^{\circ}$ 未満（ほぼ平行）が最も多く、非 軸上の場合は傾き $45 \sim 90^{\circ}$ 未満が最も多い。これは、長屋門と母屋 の双方の入口が揃って見えることが望ましいと考えられているため と推察される。母屋と長屋門が同一軸上で傾きも小さい例は 156 棟 中 81 棟と過半数を占める。これに対して、非軸上で傾きが大きい 場合は長屋門と母屋とが中庭を媒介して配置されることに变わりは なく、何らかの敷地の制約等が介在していると考えられる。

また、長屋門へのアプローチは全体として見ると、II（国道・主 要県道以外の公道) と III (私道) がほぼ同数であったが、非軸上・
傾き $45 \sim 90^{\circ}$ 未満の場合、IIがIIIのほぼ 2.5 倍の多さである。これ は、敷地に接する主要道路に長屋門を面させることで傾きが大きく なったためであり、すなわち母屋よりも道路との関係を優先したた めと考えられる。

\section{（2）母屋との関係・方位}

全体的に見ると、南向きの長屋門が 156 棟中 122 棟と最も多く、 東向きと西向きはほぼ同数である。北向きは皆無であり、鬼門を避 けた形となっている。このことから、後述する聞き取り調査もふま えると、長屋門の配置および屋敷構えは風水注8)の影響を受けている と考えられる。

母屋と長屋門が軸上にある場合は、軸上 112 棟中 108 棟が南向き とほとんどを占める。非軸上の場合、傾き $5^{\circ}$ 未満は南向き（11 棟 中 10 棟)、傾き $45 \sim 90^{\circ}$ 未満の場合は東向き（26 棟中 15 棟）と 西向き（同 11 棟）に分かれる。こうしたことから、長屋門の向き が東ないし西の場合であっても、母屋は南向きが過半であることを 示している。母屋を南向きにすることが屋敷を構える上で重要であ り、長屋門を配置する際に地形上の制約や接する道路との関係を優 先したとき、軸上からはずれ傾きが大きくなったと考えられる。

\section{（3）アプローチ・通行機能}

ほとんどの屋敷では、人・自動車ともに通行可能であるが、 156 棟中 27 棟の屋敷では、長屋門には自動車の通行機能がない $(\mathrm{Table} 2)$ 。 また、IV (アプローチなし) の 5 棟は全て自動車の通行機能はない。 これらの屋敷では、門の通路幅が狭いため人のみの利用や、通路部 分を物置に使っているため通行機能がないものがあった。この場合、
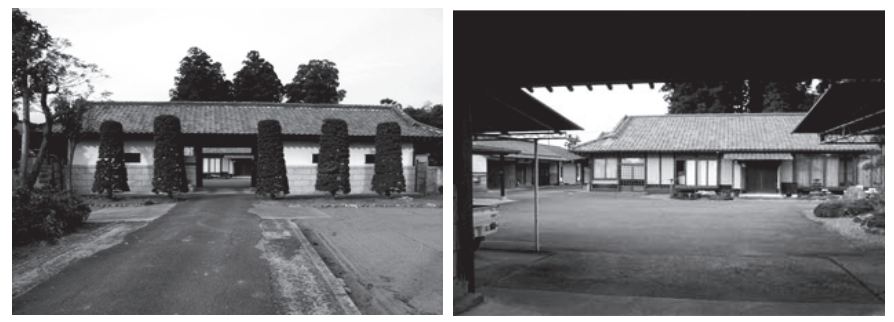

Photo1 So's front appearance of nagaya-mon (right) Photo2 So's inner court (left)

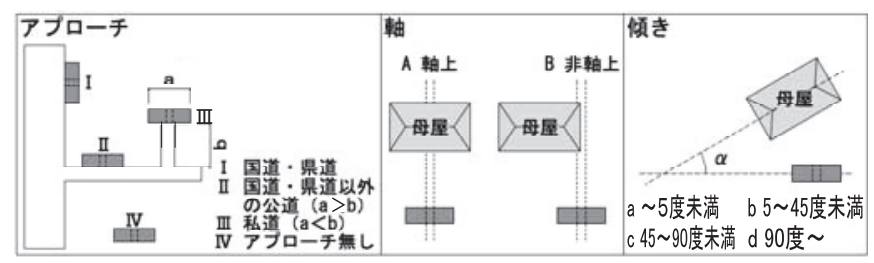

Fig.1 Classification of Nagaya-mon from setting up premises.

Table1 Classification of Nagaya-mon from approach and orientation.

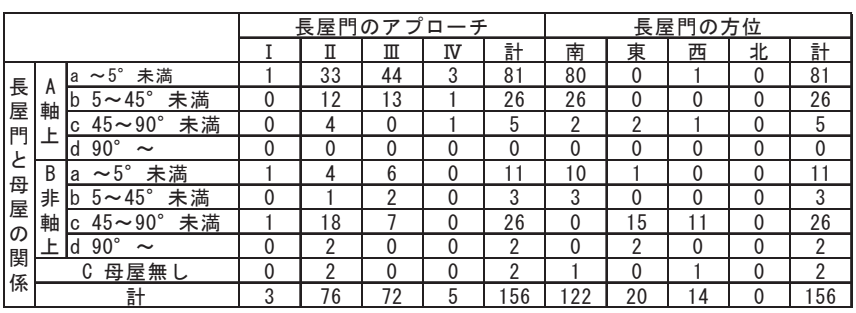

Table2 Classification of Nagaya-mon from passing.

\begin{tabular}{|c|c|c|c|c|c|c|}
\hline \multicolumn{2}{|c|}{} & \multicolumn{5}{|c|}{ 唇門のアプローチ } \\
\cline { 2 - 7 } & I & II & II & IV & 計 \\
\hline 通 & $人 \cdot$ 自動車 & 2 & 62 & 65 & 0 & 129 \\
\cline { 2 - 7 } 行 & $人$ & 1 & 6 & 4 & 2 & 13 \\
\hline 機 \\
能
\end{tabular}


自動車のアクセス路は他にあり、本来の長屋門へと続く道は用途変 更されるか、途中で曲がるなどしていた。

なお、聞き取り調查の際、屋敷の敷地面積が大きく母屋までのア プローチが長い屋敷で、消防署から消防車が進入するためのアプロ 一チをとるようかつて指導を受けたという話が聞かれた。さらに、 後述する具体例にもあるように、土地区画整理事業や道路拡張事業 などの屋敷まわりの環境変化により、長屋門へのアプローチに影響 を及ぼした場合が少なからずあると考えられる。

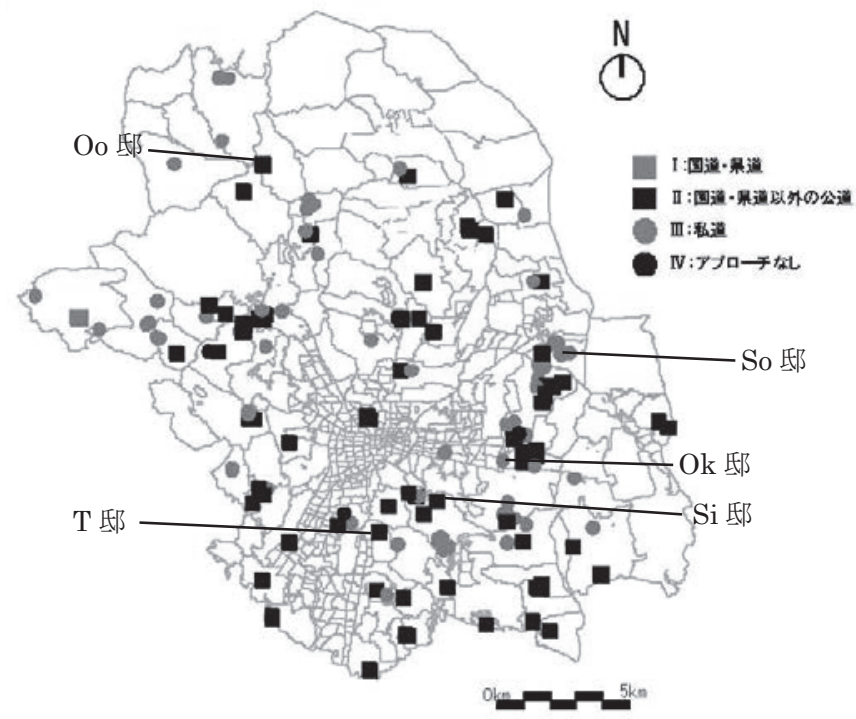

Fig.2 Distribution of approach types in Utsunomiya city.

\section{（4）地域によるアプローチの傾向}

宇都宮市の北西部は丘陵、山地が卓越し、屋敷構えに地形的な制 約が増す傾向にあるが、Fig. 2 に示すように、平坦な地形でアプロ 一チに自由度が高いと考えられる東部あるいは南部の地域と同様で、 両者のアプローチタイプに大きな傾向の差異は認められない。むし ろ、長屋門が集中している地域 (町、大字) ごとにアプローチの類 型が同一となる傾向が見られる。このことから、建設時期が比較的 短期間に集中している注9)ことを考え合わせると、長屋門をもつ既存 の屋敷構えを手本として後に続いたのではないかと推測される。

\section{3-2 屋敷構えからみた長屋門配置の傾向}

屋敷の構え方として、母屋は南向きに配置し、長屋門と母屋が平 行かつ同一軸線上に配置する形式が典型的であり、これが居住者に とって最も望ましい配置であると考えられる。しかし、屋敷地まわ りの地形・土地利用、接する道路の方位や形状などの制約から、長 屋門を東向きあるいは西向きに配置し、中庭を媒介して母屋とをつ なげる場合も少なからず見られた。

長屋門へのアプローチは、幅員の大きな道路（国県道）に直接面 するのではなく、より幅員の狭い道路に面する場合か、さらにそこ から私道を介して配置する場合が大半であることが明らかになった。 多くの事例の分析からは、長い私道のアプローチを経て門をくぐる ことを基本としていることが実証された。しかし、背後に山が迫る など地形的な制約がある場合、あるいは道路整備などにより私道の アプローチが失われるなどした場合に、直接道路に面する屋敷構え がとられると考えられる。

長屋門の配置を通行機能から見ると、十分な通行幅が確保できて
おり、かつ高さの制約には土台のかさ上げ等で対処できる場合、自 家用車等の普及に対応して、人と車の双方の通行機能が保てるもの と考えられる。これに対し、十分な幅が確保できず、高さの制約を 解消できない場合には、母屋へのアプローチ道路を新たに確保して しのぐこととなる。長屋門に引き続き人の通行機能をもたせるか否 かは、屋敷のもつ条件により左右されるであろう。場合によっては、 長屋門はその通行機能を失い、通路スペースは収納や駐車場として 使われることになる。アプローチの私道は用途変更されて畑、菜園 などになると考えられる。

このように、自家用車あるいは大型の農業機械の普及など生活・ 農業生産様式の変化は、長屋門の通行機能のみならず、屋敷構えに も影響を及ぼすことが考えられる。

\section{4。聞き取り調査と実測調査結果}

\section{4-1 事例農家における長屋門と屋敷の変遷}

屋敷構えから見た長屋門と母屋との関係、および長屋門へのアプ ローチと周辺道路との関係に関する類型分析をふまえ、典型的な 5 つの類型（II/Aa、III/Aa、II/Ab、III/Ab、II/Bc）を選定し、各々 に該当する屋敷構えの事例 1 例づつを調査対象とした。調査は、所 有者への聞き取り、長屋門および屋敷内建物配置に関する実測調查 を行い、写真撮影および図面採取にもとづく整理を行った。現在に 至る長屋門をはじめとする屋敷構えの変遷については、所有者の記 憶ならびに資料にもとづいて把握した（Fig.3、Table3）。

以下に各々の事例について調査結果を述べる。なお、選定された 調查対象の家屋敷はいずれも農家である。

\section{(1) Si 邸: II / Aa (Photo3 左)}

屋敷は宇都宮市市街地郊外の市街化区域南縁に位置する。周辺地 域で行われた土地区画整理事業により、屋敷地の南側に片側 2 車線 の市道が新設されて、屋敷まわりの防風林は宅地に転換されるとと もに、菜園は削られて敷地面積は大きく縮小した。屋敷地は広さ 3,400 m²よ゙で、屋敷地の北側には、アパートを建設した。区画整 理以前は、長屋門への南側からの私道アプローチが今よりも長かっ た。市道をはさんだ南側は市街化調整区域として田畑が広がってい る。屋敷地の西側を農業用水路が通る。

現在では農業のほか不動産業を営む。母屋は区画整理を機に 2007 年にほぼ以前の位置に新築した。母屋東側の旧来からの住居（ハナ レ）には世帯主の両親が生活する。蔵や作業舎は以前と変わらず使 用する。長屋門は享保 4（1719）年に建設されたと伝わる。1994 年に屋根を瓦に葺き替え、県道の開通に際して 2003 年に壁の漆喰 を塗り直した。間口 10 間、奥行 2 間の大きさである。

母屋と長屋門に挟まれた中庭は、以前は物干場、農作業場として 利用されていたが、現在は一面に砂利が敷かれ専ら駐車場として利 用され、その一角は鑑賞庭として低木が植樹されている。鬼門方向

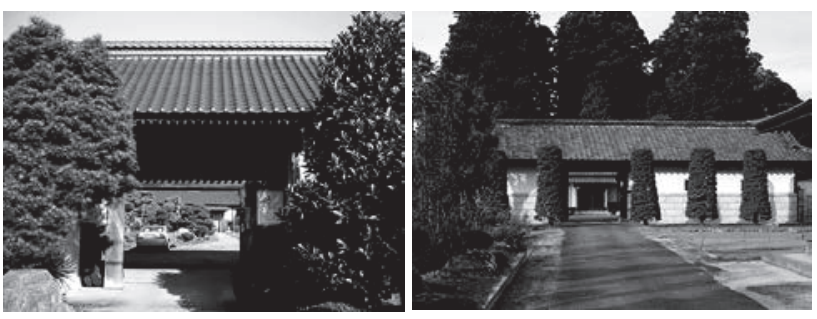

Photo 3 Si's Nagaya-mon (left ) and So's Nagaya-mon (right). 
に槐（えんじゅ）の木が植えてあり、縁起の良い木を植えることで 魔除けに効果があるとされている。

母屋と長屋門が南面し入口が軸上に並んでおり、長屋門の入り口 の先に母屋の玄関が見える。長屋門は道路（市道）に平行に配置さ れ、道路との間のわずかの空間には中低木が植栽されている。区画 整理事業ならびに市道拡幅整備事業が行われる以前は、長屋門への 長い私道アプローチを設けていた。

\section{(2) So 邸: III/Aa (Photo3 右)}

屋敷は、宇都宮市の北東部に位置し、周囲は農地に囲まれた市街 化調整区域となる農業地帯で、東には鬼怒川が流れ豊かな自然が残 る地域である。この屋敷のみならず、周辺には広大な屋敷林を構え る農家が分布して散居村の景観を呈し、そのような農家屋敷には長 屋門、あるいは四脚門注 10)が構えられている。

母屋は、1968 年に建て替えを行い、その後も 1999 年、2006 年 に台所のリフォーム、床暖房やペアガラス導入など生活の能率性、 快適性向上に努めている。附属舎もさまざまな増改築を施している ほか、1994 年には現在は娘家族が生活する住居（ハナレ）、農業機 械庫を新築した。長屋門は、明治 32 （1899）年頃に建設された。 間口 10.8 間、奥行 2.8 間の大きさで間扉が備わっている。1950 年 に大規模な改修を行っており、土台を玉石からコンクリートに、腰 壁を板張りから大谷石積夕にした。天井も高くしたとのことで、自 家用車の普及に対応した工事と推測される。

真南、真東などは避けるように母屋、長屋門ともわずかに角度を ふって配置され、母屋からみた鬼門の方向には建物の配置を避ける など、方位を考えて造られているとのことである。

中庭と鑑賞庭が塀で仕切られることで、中庭は来訪者も含む公的 な空間、鑑賞庭は家族のための私的な空間としてゾーニングされて いる。また、長屋門の南側には菜園が設けられ、周囲の農地と連続 させることで、外部と屋敷との中間領域の役割を果たしている。全 体的に風水の考えにもとづいた屋敷構えがなされ、水路は鬼門方向 を欠くとともに、敷地内の持仏堂、母屋、鳥居が一直線上になるよ うに配置されており、計画的な屋敷造りがうかがえる。

\section{(3) 00 邸: II / Ab (Photo4 左)}

宇都宮市の北西部に位置する農村地域に、北側に山を抱えて屋敷 構えがなされる。南側に農地が広がり、東側に向かって谷が開く地 形である。谷の出口には南北に日光街道が通り、現在では平行して 自動車専用道である日光宇都宮道路がある。山に向かって傾斜して いるため、屋敷は農地からやや上がった高台にあり、南面を除く屋 敷地の三方向には屋敷林が配されるため、屋敷全体が山と景観的に
一体化しており、長屋門はその入口として存在感をもつ。本来は長 い私道からのアプローチだったが、耕地整理の際に用途変更され、 現在は屋敷地の前面は農地（水田）となった。

現在も農業を営む農家であり、三世代が同じ母屋内に生活する。 母屋は、2006 年に新築された。屋敷東側にはかつての住居（インキ ヨヤ）が現在は使われずに建っている。かつての母屋は 1840 年頃 に家畜を飼っていた曲り屋を建て替えたといわれる。長屋門は 1830 年頃（天保年間）に現在のものに新築したと伝わる。間口 7.5 間、 奥行 2.5 間で間口がやや小さい。これは屋敷地の制約によると考え られる。敷地面積は約 $3,000 \mathrm{~m}^{2}$ と調查事例の中では相対的に小さい。

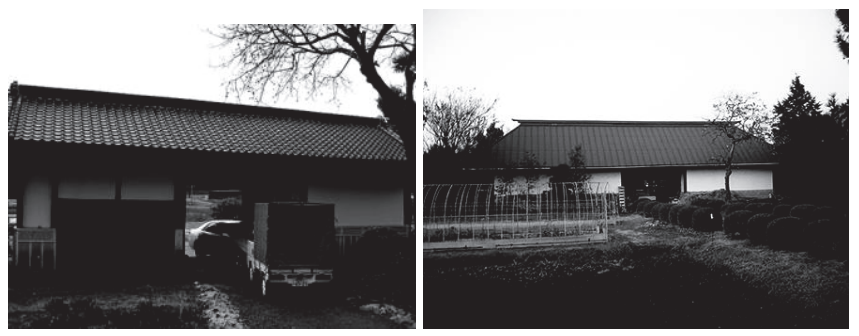

Photo 4 Oo's Nagaya-mon (left ) and Ok's Nagaya-mon (right).

屋敷内には、他に蔵、倉庫、作業舎 (アマヤ)、鑑賞庭が配される。 蔵の屋根は大谷石類似石である徳次郎石が使われている。かつては 長屋門も同じ石瓦であったが、1993 年に現在の栈瓦に莫き替えられ、 あわせて漆喰壁の塗り替えも行われた。2006 年の母屋建て替え時に トラックなどの大型車が通る道として、長屋門の東脇を通るアプロ ーチ路が新たに設けられたため、長屋門は人の通行機能だけが残っ た。自家用車の雨よけ車庫として使用されている。長屋門と母屋は 同一軸上にあるが、屋敷地の地形的な制約からわずかに傾きがある。

(4) Ok 邸： III/Ab (Photo4 右)

屋敷地は宇都宮市の東部に広がる鬼怒川右岸の低平な田園地域に 立地する。西側は河岸段丘となって高く、南北に通る水路で屋敷が 区切られる。段丘上は市街化区域であり、宇都宮市の市街化区域の 東縁に位置する。

第二次大戦中の戦災により長屋門と土蔵以外の建物が焼失したた め、作業舎の位置などは現在とはやや異なる。母屋は戦後すぐに以 前とほぼ同じ場所に再建され、さらに 2002 年に現在の住宅に建て 替えられた。現在は世帯主と長男家族が一緒に生活している。1988 年には屋敷地の東側に二男家族の住居（ハナレ）が建設された。農 業のかたわら建設業も営む。屋敷地北側に広く作業場を設けている。 長屋門は慶応 3 （1867）年の建設と伝わり、間口 12 間、奥行 2.5 間と大きい。1966 年に屋根を茅莫きから金属板莫きに変え、外壁の

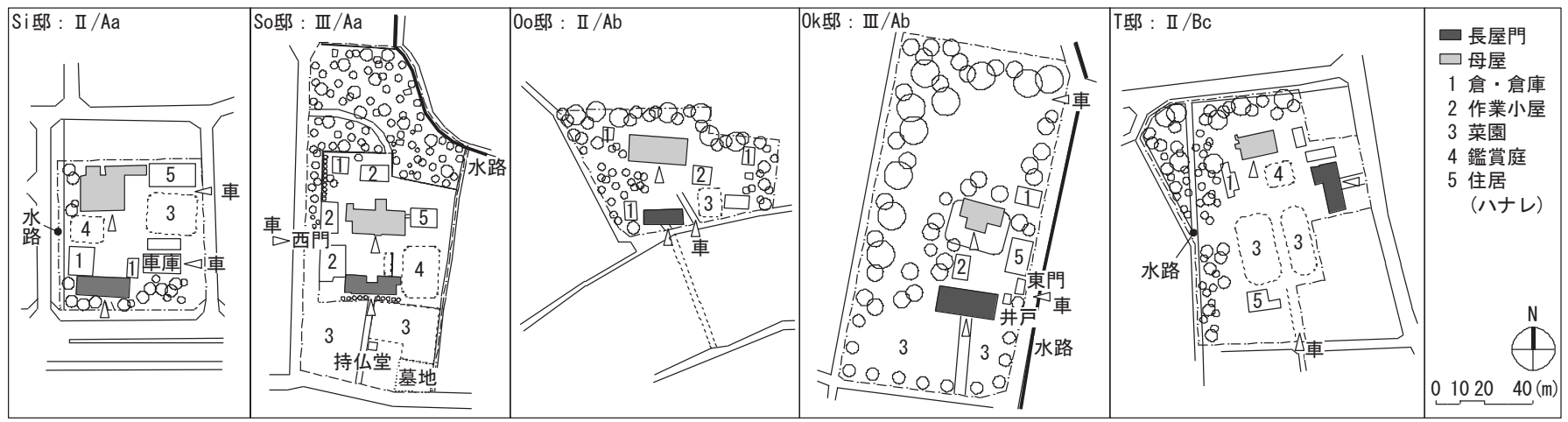

Fig.3 Outline of field survey of the chosen farmhouses. 
Table3 Outline of hearing investigation to the chosen farmhouses.

\begin{tabular}{|c|c|c|c|c|c|c|c|}
\hline & Si 邸 & So邸 & 0o邸 & Ok邸 & T邸 \\
\hline \multirow{3}{*}{$\begin{array}{l}\text { 増 } \\
\text { 改 } \\
\text { 築 } \\
\text { の } \\
\text { 有 } \\
\text { 無 } \\
\text { - } \\
\text { 時 } \\
\text { 期 }\end{array}$} & \multicolumn{2}{|c|}{ 長屋門 } & $\begin{array}{l}\text { 1994年：屋根/瓦莫 } \\
\text { き替え } \\
\text { 2003年：壁/漆喰塗 } \\
\text { 直し }\end{array}$ & 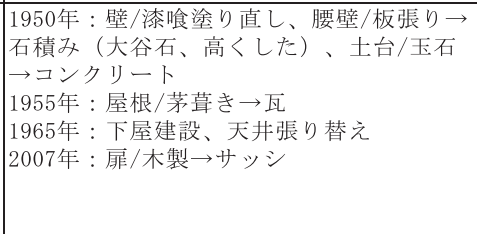 & $\begin{array}{l}\text { 1945年: 壁/漆喰補正 } \\
\text { 1993年: 屋根/石瓦 (徳次郎 } \\
\text { 石) } \rightarrow \text { 瓦、壁/漆喰補正、腰 } \\
\text { 壁/石積み補正 }\end{array}$ & $\begin{array}{l}\text { 1966年: 屋根/茅葺き } \rightarrow \text { 南 } \\
\text { 間式トタン、壁/漆喰塗直 } \\
\text { L } \\
\text { 1968年 : 腰壁/石張り } \rightarrow \text { ブ } \\
\text { ロック }\end{array}$ & 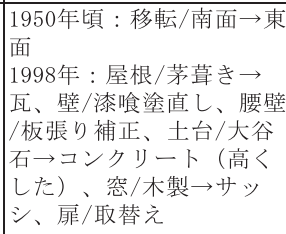 \\
\hline & \multicolumn{2}{|c|}{ 母屋 } & 2007年：増改築 & $\begin{array}{l}\text { 1968年：建替え } \\
\text { 1999年：床に断熱材を貼る、台所をリ } \\
\text { フォーム } \\
\text { 2006年：空をペアガラスに取替え }\end{array}$ & $\begin{array}{l}\text { 1840年頃：曲り屋 } \rightarrow \text { 長屋 } \\
\text { 1985年頃：基礎を替える } \\
\text { 2006年：改築 }\end{array}$ & $\begin{array}{l}\text { 戦後初期：建替え } \\
\text { 2002年：建替え }\end{array}$ & 1950年頃：建替え \\
\hline & \multicolumn{2}{|c|}{ 付属建物 } & 建替え無し & 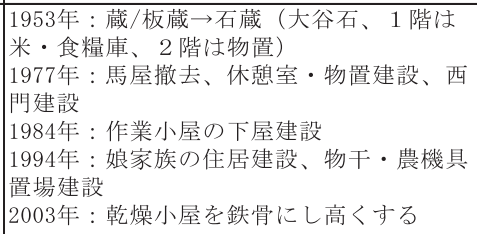 & 1924年：あまや建設 & $\begin{array}{l}\text { 1988年：現在次男の住居 } \\
\text { 2001年 : 土蔵撤去、事務 } \\
\text { 所建設 }\end{array}$ & $\begin{array}{l}\text { 1950年頃：小屋建設 } \\
\text { 2003年：娘家族の住居建 } \\
\text { 設 }\end{array}$ \\
\hline \multirow{4}{*}{$\begin{array}{l}\text { 利 } \\
\text { 用 } \\
\text { 用 } \\
\text { 途 }\end{array}$} & \multirow{2}{*}{$\begin{array}{c}\text { 長屋 } \\
\text { 門 }\end{array}$} & 昔 & $\begin{array}{l}\text { 米倉、肥料・農具置 } \\
\text { 場 }\end{array}$ & 農業用品・生活用品置場 & 住宅、農機具・肥やし置場 & かんぴょう干場、米倉 & 農作物保管 \\
\hline & & $\begin{array}{l}\text { 現 } \\
\text { 在 }\end{array}$ & 生活物置 & 農業用品 - 生活用品置場、食料貯蔵庫 & 物置 & 農業機器置場、倉庫 & 倉庫、乾燥機置場 \\
\hline & \multirow{2}{*}{\begin{tabular}{|l|} 
屋 \\
と長 \\
屋門 \\
の間 \\
の庭 \\
\end{tabular}} & 昔 & $\begin{array}{l}\text { 土間、干し物、農作 } \\
\text { 業 }\end{array}$ & 作業場、もみ干場、馬屋の橖置場 & 庭、畑 & もみ干場 & 干し物、農作業 \\
\hline & & $\begin{array}{l}\text { 現 } \\
\text { 在 }\end{array}$ & $\begin{array}{l}\text { 庭園、駐車場（砂利 } \\
\text { 敷き） }\end{array}$ & 駐車場（コンクリート敷き） & 庭 & 特に無し（砂利敷き） & 庭園 \\
\hline \multicolumn{3}{|c|}{$\begin{array}{l}\text { 屋敷に接す } \\
\text { る道路の変 } \\
\text { 化 }\end{array}$} & \begin{tabular}{|l|} 
細い道 $\rightarrow 5 \sim 6 \mathrm{~m}$ 幅の \\
道 \\
$\rightarrow 4$ 車線
\end{tabular} & 舗装された & $\begin{array}{l}\text { 2006年: 屋敷沿いの道は工事 } \\
\text { の時トラックが通る道として } \\
\text { つられた }\end{array}$ & $\begin{array}{l}\text { 1995年：土地改良により } \\
\text { 碁盤の目状に舖装 }\end{array}$ & $\begin{array}{l}\text { 東面の道路が拡張され交 } \\
\text { 通量も増大 }\end{array}$ \\
\hline \multicolumn{3}{|c|}{$\begin{array}{l}\text { 屋敷づくり } \\
\text { についての } \\
\text { 昔からの決 } \\
\quad \text { ま事 }\end{array}$} & $\begin{array}{l}\text { ·鬼門の方向に槐の } \\
\text { 木が植えてあった。 }\end{array}$ & $\begin{array}{l}\text { ·敷地の入口は八の字にしている。 } \\
\text { ・真南、真東などは避け敷地全体がやや西 } \\
\text { に傾けている。 } \\
\text { ·敷地に対して門道は西に傾けている。 } \\
\text { ·敷地の形は鬼門方向部分を欠いている。 }\end{array}$ & $\begin{array}{l}\text { ·床柱を中心に考える。 } \\
\text { ・水場は鬼門を避ける。 } \\
\text { ·門道は門に対して傾ける。 } \\
\text { ·真南、真東などは避ける。 }\end{array}$ & $\begin{array}{l}\text { ・八口・水場は鬼門を避 } \\
\text { ける。 } \\
\text { ・辰巳井戸は縁起が良 } \\
\text { い。 }\end{array}$ & 特に無し \\
\hline \multicolumn{3}{|c|}{ 備考 } & $\begin{array}{l}\text { ・門の両側に麒麟の } \\
\text { 絵がある。 }\end{array}$ & $\begin{array}{l}\text { ・長屋門の扉に乳鋲がある。 } \\
\text { ・屋敷敷地境界を土盛りし植木を植えてい } \\
\text { た、敷地内に鳥居が } 3 \text { 箇所ある。 }\end{array}$ & $\begin{array}{l}\text { ・長屋門から母屋までが少し } \\
\text { 傾斜になっている。 }\end{array}$ & 特に無し & $\begin{array}{l}\text { ・柱が } 4 \text { 本の門形式。 } \\
\text { ・戦前は敷地全体を土も } \\
\text { りして囲んでいた。 }\end{array}$ \\
\hline
\end{tabular}

漆喰を塗り直している。

長屋門と母屋で挟まれる中庭は、以前は稲粐の干場として使用し ていたが、乾燥機を導入して粐を乾燥させるようになったため、そ の用途がなくなり、現在は一面に砂利を敷き駐車場などとして使用 している。この中庭はハナレと母屋を結ぶ役割を果たしている。

耕地の区画整理により碁盤の目状に道路が舗装され、直線的な道 路になった。また、以前は敷地の東側のすぐ脇に水路があり、敷地 境界を形成していたが、区画整理の際に道路がすぐ脇に舗装され、 現在の水路は道路の東側にある。中庭には東門を設けて車の出入り に使用している。

全体の敷地は広く、建物配置ゾーンは中央部のやや道路側に寄せ て設けられ、北は防風林、南は菜園になっている。敷地周囲は畑が 多く、敷地内の菜園が外部と屋敷との中間領域の役割を果たしてい るように見える。しかし、新しく事務所・作業小屋を中庭西側に建 設したため、長屋門から見ると母屋が少し隠れてしまっている。

(5) T 邸 : II/Bc (Photo5)

屋敷地は、宇都宮市の市街地南縁に位置し、東側を東北新幹線が 走り、西側を田川が流れる。敷地は自動車交通量の多い旧街道に接 する。

家は昔から農業を営んでいた農家であり、戦前までは地主であっ た。母屋も含めて多くの建物は建て替えや新築、移築されており、 昔の屋敷構えと異なる点が多い。母屋は 1950 年頃に新築され、同 時期に倉庫も建設された。屋敷地の南側に住居（ハナレ）を2003
年に建設し娘家族が居住している。長屋門は母屋の新築と同時期に 移築が行われた。すなわち、以前の長屋門は敷地の南側にありアプ ローチも長い私道が配されており、長屋門と母屋は同一軸線上に配 されていたが、幅員の大きな旧街道の道路からのアプローチとする ため母屋の東側に移築した。このため母屋と長屋門のそれぞれの軸 線がほぼ直交するようになった。移築した長屋門と道路との間のわ ずかな空間には中低木が植栽されている。長屋門を東側に移築した 理由は、家の出入口である長屋門を交通量の多い道路に面させ屋敷 の存在を引き立たせること、および、自動車の通行に不便な門の通 行機能を主に人に限定させ自動車は従来通り南側からアプローチさ せるという複合的なものであった。

長屋門は 1860 年より以前の建築と伝わっており、間口 9.5 間、 奥行 2.5 間で腰壁は板張り、漆喰塗仕上げである。門の出入口部分 に柱が 4 本立っており室から独立した珍しい門形式である。四脚門

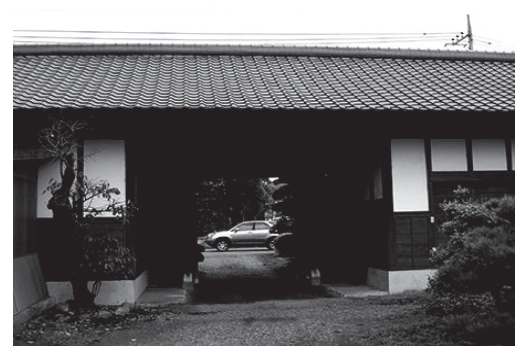

Photo 5 T's Nagaya-mon from inner court. 


\section{との折贵形式を想起させる。}

母屋と長屋門とをつなぐ中庭は、以前は前述の Ok 邸と同様、農 産物の干場や農作業場として使用していたが、乾燥機を使い乾燥さ せるようになったため用途がなくなり、現在は鑑賞庭として利用し ている。屋敷地の北側と西側は防風林や水路で区画されている。

\section{4-2 事例からみた屋敷構えの変遷と長屋門の役割}

屋敷地の北側および西側は冬の季節風を防ぐために屋敷林が配さ れる場合が多く、これに水路で敷地を区画している。また、長屋門 と道路との間は菜園とするか中低木が植栽されている。

母屋と長屋門とは中庭スペースを媒介してつながり、以前は農作 業場など農業経営上の役割を果たしていたが、現在では主に生活上 の多用途な空間となっている。

長屋門へのアプローチは、南からの長い私道を基本としていたが、 耕地整理や土地区画整理などにより屋敷地周辺の道路形状が変わる ことにより短くなる場合、あるいは、長屋門を移築してアプローチ 自体を変更する場合などが見られた。新たな門の新設や車のための アプローチ路の新設などにより、長屋門の通行機能が限定されるよ うにもなっている。

長い私道のアプローチを残す場合は、両側は菜園となっており、 屋敷地の内外を結ぶ中間領域を形成する。したがって、長屋門は屋 敷内とこの中間領域を明確に区画する境界の意味をもつと考えられ る。

\section{5. 結論}

杤木県宇都宮市を対象に、屋敷構えという概念を手がかりとして 長屋門について、母屋をはじめとする屋敷内の諸要素および周辺環 境との関係から分析を行った。本研究を通して明らかになった事項 は以下のようである。

1）長屋門をもつ屋敷の母屋は、大半が南を向く配置をもち、長屋 門はこの母屋と同じ軸上に出入口をもって棟方向を東西に延 ばす、すなわち長屋門は南を向くという事例が 8 割近くを占め た。北を向く事例は皆無であった。

2）上記のような母屋ならびに長屋門が同一軸上に位置して南を 向くものを典型と見た場合、典型からはずれる事例では、道路 との関係を優先し、または屋敷周囲の地形的な制約などにより、 長屋門と母屋が同一軸上になく、あるいは長屋門が東ないし西 を向くと考えられる。

3）長屋門と道路との関係では、国道・県道などの主要道路に直接 面する長屋門は少なく、その他の公道に面する長屋門と私道に 面する長屋門がほぼ同数で、それぞれ 5 割近くを占める。

4）事例を含めた考察から、長屋門へのアプローチは、屋敷地内に おける南からの長い私道を基本とすることが明らかとなった。 なお、長屋門の配置に関する類型の地域的な分布は、平坦な農地 が広がる地域と丘陵・山地が絡む地域とで明確な差異は見られず、 同一大字など小地域内において同一の類型が集まる傾向が観察され た。こうした地域的な傾向を生む背景の解明は今後の課題としたい。

5 つの事例分析から、長屋門は屋敷構えの重要な要素として居住 者に意識されており、風水（家相）の考え方が強く影響している。 また、屋敷地と周辺とを画地する境界要素として、屋敷林、水路、 塀などと同じ機能を果たすが、内外をつなぐ門として、門の手前に
ゆるやかな中間領域を形成する独自の機能も果たしていると言える。 さらに、屋敷周辺における道路拡張・新設事業、土地区画整理事 業、圃場整備事業など、自家用車や大型農業機械の普及などにより、 長屋門へのアプローチが変化していることが明らかとなった。この ことをふまえると、公道から一定の私道アプローチをとる、すなわ ち内外をゆるやかに画地する長屋門が屋敷構えの規範としてあった ことが推測される。いずれにせよ、長屋門は屋敷構えを構成する諸 要素の中では重要な位置を占めており、特に、居住者の内的な生活 要求と対社会的関係とが統合的に反映した存在であることが明らか になった。

末尾ながら、本編をとりまとめるに当たり、橋田祥子（小山市役 所)、田中 (酒井) 智季の両氏ならびに長屋門所有者各位には、調査 ならびにとりまとめで大きな支援をいただいたことを記して謝意を 表する。

\section{注}

注 1) J. Lang : Urban Design -The American Experiences-, 1994, p.249（著者訳）

注 2）参考文献 6) を参照。

注 3) 参考文献 7) を参照。

注 4) 参考文献 6) を参照。

注 5）参考文献 8) を参照。

注 6）参考文献 9)を参照。

注 7）農村系長屋門とは、市街地系長屋門に対比されるものとして、主に農村 に立地する長屋門を指寸。かつては農家長屋門と呼称してさしつかえなか ったが、農業を営む農家ではない家も含まれるようになったことから農村 系長屋門とした。

注 8）古代中国に起源をもち東アジアを中心に広がった、建物や都市の位置の 吉凶禍福を決定するために用いられた思想と実践的手法であり、日本では 家相として発展した。家相においては、鬼門（北東方位）、裏鬼門（南西 方位）などへの配慮が屋敷構えや母屋の間取りに影響を及ぼしている。

注 9）参考文献 3) 参照。

注 10）門の建築様式のひとつで、門柱の前後に控柱を 2 本ずつ、左右合わせ て 4 本立てたもの。正門に配されることの多い格式の高い門とされる。

\section{参考文献}

1) Hashida Y., Sakai T., Mitsuhashi N. and Honjo H.: On 'Nagayamon 'Gate's Approach and Location toward the Main House, Summaries of Technical Papers of Annual Meeting Architectural Institute of Japan, E-2, pp.451-452, 2010.9 (in Japanese) 橋田祥子・酒井智季・三橋伸夫・本庄宏行 : 長屋門のアプローチおよび母 屋との関係一宇都宮市における長屋門のある屋敷構えに関する研究その 1 一, 日本建築学会大会学術講演梗概集, E-2, pp.451-452, 2010.9

2) Sakai T., Hashida Y., Mitsuhashi N. and Honjo H.: On Spatial Composition of Residential Site with Nagayamon Gate, Summaries of Technical Papers of Annual Meeting Architectural Institute of Japan, E-2, pp.453-454, 2010.9 (in Japanese)

酒井智季・橋田祥子・三橋伸夫・本庄宏行 : 長屋門をもつ屋敷の空間構成 一宇都宮市における長屋門のある屋敷構えに関する研究その 2 - , 日本建 築学会大会学術講演梗概集, E-2, pp.453-454, 2010.9

3) Mitsuhashi N. and Honjo H.: Utilization and Sustainability of Nagaya-mon Gate in Rural Area -Case studies of Utsunomiya city and Takanezawa town in Tochigi prefecture-, Journal of Architecture and Planning (Transactions of AIJ), No.732, pp.403-409, 2017.2 (in Japanese)

三橋伸夫・本庄宏行 : 農村系長屋門の利活用実態とその持続性に関する研 究一栃木県宇都宮市・高根沢町を中心とした事例的検討一, 日本建築学会 計画系論文集，第 732 号, pp.403-409, 2017.2

4) Yamada T., Tsukidate T., Noguchi T., Morishita M., Nishimura S. and Sumiya H.: Study on the Spatial Characteristics of Farmhouse in Hokkaidou, Technical Papers of Annual Convention of Tohoku Branch, 
pp.285-288, 2007.6 (in Japanese)

山田徹・月舘敏栄・住谷浩他 : 北海道農村住宅の屋敷構えに関する研究, 日本建築学会東北支部研究報告会, pp.285-288, 2007.6

5) Yamada T., Tsukidate T., Noguchi T., Morishita M., Nishimura S. and Sumiya H. et al.: Study on the Changing Process of Farmhouses in Hokkaidou, Summaries of Technical Papers of Annual Meeting Architectural Institute of Japan, E-2, pp.513-514, 2007.8 (in Japanese) 山田徹・月舘敏栄・住谷浩他 : 北海道農村住宅の変容過程に関寸る研究一 2005 年追跡調査の結果その 9 営農形態による屋敷構えの特徴一, 日本建 築学会大会学術講演梗概集, E-2, pp.513-514, 2007.8

6) Tsukidate T., Sasaki Y. et al: A Study on House Site Style of Urban Houses in Tohoku District, Summaries of Technical Papers of Annual Meeting Architectural Institute of Japan, E-1, pp.81-82, 1985.10 (in Japanese)

月舘敏栄・佐々木嘉彦・外 : 東北地方都市住居の屋敷構えについて, 日本 建築学会大会学術講演梗概集, E-1, pp.81-82, 1985.10

7) Tsukidate T.: A Study of Growing Process in Fishing Village part2 -Home Site Design Method and Growing Process-, Summaries of Technical Papers of Annual Meeting Architectural Institute of Japan, Rural Planning, pp.1917-1918, 1983.9 (in Japanese)
月舘敏栄 : 漁業集落の形成過程の研究 2 -屋敷構えと形成過程-, 日本建築 学会大会学術講演梗概集, 農村計画, pp.1917-1918, 1983.9

8) Kurono H. and Kikuchi S.: The Spatial Composition of Street Villages and its Connection with Streets and Watercourses, Journal of Architecture and Planning (Transactions of AIJ), No.537, pp.165-170, 2000.11 (in Japanese)

黒野弘靖・菊地成朋 : 街路村における街路と水路の中心性と屋敷構えとの 関係一砺波散居村における居住特性の分析その 4 -, 日本建築学会計画 系論文集第 537 号, pp.165-170, 2000.11

9) Hoshina Y. and Kurono H.: The Traditional Arrangement of Buildings for the Management of Snowy Environments through Yoko-ido Watercourse System, Journal of Architecture, Planning and Environmental Engineering (Transactions of AIJ), No.506, pp.89-93, 1998.4 (in Japanese)

星名康弘・黒野弘靖 : 横井戸を利用した伝統的な雪処理システムと屋敷 構えとの関係一新潟県川西町<小脇 $>0$ 事例検討一, 日本建築学会計画系 論文集第 506 号，pp.89-93, 1998.4

10) Yoshio Watanabe: Theory of Fengshui and East Asia, Jimbun Shoin, 1994 (in Japanese)

渡邊欣雄 : 風水思想と東アジア，人文書院，1994 


\title{
LAYOUT OF NAGAYA-MON GATE IN RURAL AREA FROM A VIEWPOINT OF SETTING UP PREMISES
}

A case study of Utsunomiya city in Tochigi prefecture

\author{
Nobuo MITSUHASHI* and Hiroyuki HONJO** \\ * Honorable Prof., Utsunomiya University / President, Tochigi Partnership Design League, Dr. Eng. \\ ** Technical Staff, Faculty of Regional Design, Utsunomiya University
}

Nagaya-mon gate is one of factors consisted of farmhouse premises. The paper aims to clarify layout conditions of the gate focusing on setting up premises of farmhouse. Utsunomiya city in Tochigi prefecture were chosen for investigation because many Nagaya-mon gates of rural type still exist in the area. Through map surveys on web browser and field studies, all gates in the city were categorized into several types from view-points of gate's attributes, such as orientation, common axis with main house, and connection of public road adjacent to the site. The conclusions introduced from the analyses can be summarized as follows:

1) Both main houses and Nagaya-mon gates mostly face the south, and the layout of the premises shows that main house and Nagaya-mon gate have common axis along each approach with parallel position;

2) four fifth of the cases correspond with the previous relation, and no Nagaya-mon gate facing the north is observed;

3) assuming the typical case mentioned above, cases not applicable to the type seem to be caused by some conditions such as relation to the adjacent road, restriction due to landform of the site, and are consequently considered that Nagaya-mon faces the east or west with no common axis between the main house;

4) few Nagaya-mon gates face local main road like the national and the prefectural road, while the others mainly face inferior public roads or private roads;

5) considering the transition of the surroundings, original Nagaya-mon gate is assumed to have a private approach on its own site.

Categorizing the cases from view-points of the Nagaya-mon gates' orientation, relation to main house and the adjacent road, distribution of the categories don't apparently shows any differences between plain areas and mountainous area, but cases of the same category concentrate in each local area. A hypothesis can be introduced that an existing Nagaya-mon gate and its surroundings must have presented a norm or standard at that time when gates enthusiastically built in each area.

Taking findings from five case studies of time sequence analysis into consideration, it can be said that residents generally consider layout of the Nagaya-mon gates as important factor of their premises and seem to be affected by physiognomy of a house. Nagaya-mon gate not only functions as a boundary between inside and outside of the homestead like premises forest, watercourses and fences, but also uniquely presents an intermediate space between private and public zone. In addition, approach to Nagaya-mon gates is likely to have changed because of projects of extending roads, land reallocation or farm land consolidation, popularization of automobiles and agricultural machines. Nagaya-mon gate integrates resident's inferior needs of life and exterior social relations to community. 